\title{
The Effect of Perception of Use, Ease, Security and Confidentiality to Use E- Filing (Study in The Tax Office Pratama Raba Bima)
}

\author{
${ }^{1}$ R. Ayu Ida Aryani ${ }^{2}$ Rr. Titiek Herwanti ${ }^{3}$ Prayitno Basuki \\ ${ }^{1}$ Economics and Business Faculty Mataram University Indonesia \\ ${ }^{2}$ Lecturer, Mataram University, Indonesia \\ ${ }^{3}$ Lecturer, Mataram University, Indonesia \\ Email: ayuaryani13@yahoo.co.id
}

\begin{abstract}
The research aim to examine and analyze the effect of perception of use, perception of ease, security and confidentiality to use of e-filing of the corporate taxpayer. The population in this study the number of taxpayers registered in the Tax Office Pratama Raba Bima which consists of Dompu Regency, Bima and Bima City amounted to 350 corporate taxpayers. The sampling technique is done by proportional stratified random sampling of 75 taxpayers. The research instrument is in the form of questionnaire and the data is analyzed with Smart PLS 2.0. The results showed that perception of use, perception of ease, security and confidentiality have positive and significant effect on the use of e-filing.
\end{abstract}

Keywords: perception of use, perception of ease, security and confidentiality, use of e-filing

\section{Foreword}

Tax is one of the largest sources of state revenues. Tax revenues play an important role in the welfare of the people in Indonesia. Therefore the results of tax levies in our country at the present time become the main source of state revenues whose contribution is expected to increase every year. Thus, various attempts have been made by the apparatus of the Directorate General of Taxes in increasing the state revenue from taxes, then the reforms are made in the tax system.

The Directorate General of Taxation has implemented an electronic archive, which is an update in the taxation system. Various breakthroughs associated with the application of information technology in tax activities continue to be done in order to facilitate, improve and optimize services to taxpayers. E-filing or electronic filing system is a system of reporting or submitting of tax with Letter of Notification (SPT) electronically done through real time online system through internet on website of Directorate General of Tax or Service Provider.

Anticipating the development of information and technology, the Directorate General of Taxation seeks to meet the aspirations of Taxpayers by facilitating the procedures of reporting the SPT either SPT Time or SPT Annual. The Director General of Taxation issued the Decree of the Director General of Taxes Tax No. KEP-88 / PJ / 2004 dated May 14, 2004 concerning the delivery of Electronic Notification Letter. After the success of the e-SPT program, the Directorate General of Taxation issued a decree KEP-05 / PJ / 2005 stipulated on January 12, 2005 on the procedure of delivering e-filing by applying Service Provider (ASP). The use of e-filing is expected to provide ease and comfort for Taxpayers in preparing and submitting SPT. But in practice there are still many taxpayers who consider that the use of computer systems in the reporting of the Notice (SPT) is very confusing and difficult. This is because there are still many taxpayers have not understood about the operation of e-filing and the ability of taxpayers to use e-filing is still minimal

Literature Review And Formulation Of Hypotheses

Information Technology System 
Information technology systems known as management information systems, functional information systems, that are systems applied in organizational functions (Jogiyanto, 2010: 4). Basically the information system is the application of computer technology on functional information systems that are considered capable of providing added value to the organization.

In the world of taxation, one form of application of information systems is the development of online SPT reporting services (e-filing). In e-filing there are many applications of technology both in the form of hardware and software

\section{Technological Acceptance Model (TAM) Theory}

Technologi Acceptance Model Theory is a model that predicts and explains how technology users receive and use the technology in individual user work (Davis, 2000), with a view to describing the individual's attitude regarding the acceptance of the use of a technology.

The Model Technologi Acceptance Model (TAM) model developed by Davis (1989) is a successful and highly acceptable model for predicting acceptance of a newly applied technology. For now, TAM is one of the most important theoretical contributions to the reception and use of an information system. Many studies have researched, expanded, and used TAM.

\section{Task Technology Fit (TTF) Theory}

Task Technology Fit Theory developed by Goodhue and Thompson (1995), is the level by which technology helps individuals in the implementation of tasks supported by the function of technology (e-filing). The success of the information system is determined by the implementation of the system, the ease offered to the user, and the perceived usefulness of the technology in performing the task.

A system is considered positive if the system can meet the needs of user tasks other than the other characteristics that exist on the system (Goodhhue and Thompson, 1995. Task Technology Fit theory stated that a technology will be used if and only if the existing function in the technology supports the activity of the user means the user will select the tools and methodologies that enable to complete the task in the best way so that technology that does not provide enough benefits will be abandoned

\section{E-Filing}

According to the Regulation of the Directorate General of Taxation Number PER-47 / PJ / 2008 on Procedures for Submission of Letter of Notification and Submission of Extension of Electronic Annual Letter (e-filing) through Application Service Provider Company (ASP,e-filing is a way of delivering the Annual SPT and the submission of Annual SPT renewal notification which is done online and real time through Application Service Provider (ASP).

E-filing fittings include Application Provider (ASP), application for e-FIN or Electronic Filing Identification Number, Digital Certificate, e-SPT, receipt of e-SPT.

\section{Perception}

Perception is the process by which a person can choose, receive, interpret information to be exposed to the environment (Robins, 2008), or the level of understanding of a person when viewing information according to the person's point of view.

\section{Perceptions of Use}

Perceptions of Use is something that states individuals believe that the use of a particular technology will improve the performance of the individual. The perception of utility directly affects the intention to try and use the e-filing system, if the taxpayer feels the benefit will intend to use the e-filing system, otherwise if the taxpayer does not feel the benefits of the system then will not intend to use it (Susanto, 2011).

\section{Perceptions of Ease}

Chen et al (2011) defines perceptions of ease as the degree to which individuals believe that the use of a particular information or information technology system does not require much effort.

A system can be said to be quality if the system is designed to meet user satisfaction through the ease of using the system, ease of use not only the ease to learn and use a system but also refers to the ease of doing a 
job or task where users of a system will make it easier for someone in working than manually (Pratama, 2008 in Desmayanti, 2012).

\section{Security and Confidentiality}

Security and confidentiality are how strong the security features and the confidentiality of technological devices to maintain data security and confidentiality (Wibisono and Agus, 2014). Hamlet and Strube (2000) state that security and confidentiality as the use of information systems is safe, the risk of data loss or information is very small, confidentiality of all matters relating to the user's personal information, this means that security and secrecy are positive aspects that e-filing systems that affect the degree of use of such systems

To clarify the effect of each variable, it can be described as follows model

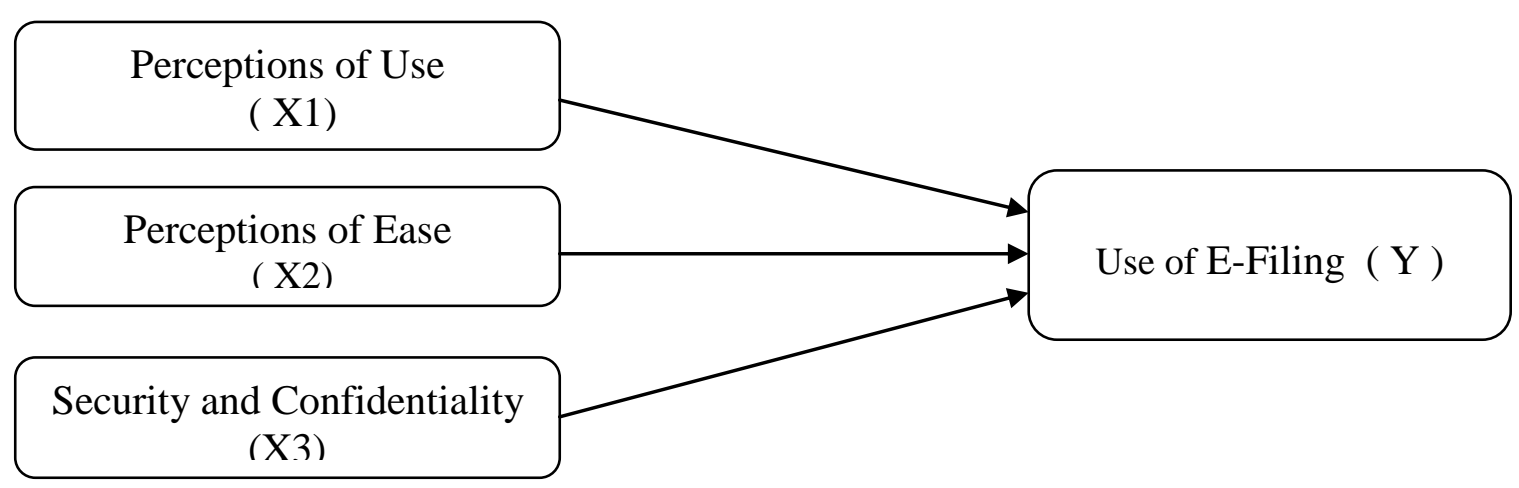

\section{Development of Hypotheses}

Figure 1. Research Model

\section{The Effect Of Perception of Use to Interest in the Use of E-filing}

Technology Acceptance Model Theory describes and estimates user acceptance of an information system, and explains the causal relationship between belief in the benefits of an information system and its ease of use. Perceived usefulness of size where a person believes that a technology will benefit the individual who uses it, if the user interprets that e-filing provides benefits in the submission of the tax report, the Taxpayer is directly encouraged to use it (Wiyono, 2008). If the perception of high use then the taxpayers interest in using e-filing is also great.

The results of previous research conducted by Laihad (2013), Noviandini (2012), Puspa (2012), wang (2003), stated that the perception of utility positively and significantly affect the use of e-filing, but unlike the results of research conducted by Salim (2013), Wahyuni (2015) which states that use perception has no effect on interest in using e-filing.

Based on the theory, literature review and the results of previous research, it can be formulated hypothesis that is:

\section{H1: Perceptions of use has a positive effect on the use of E-Filing}

\section{The Effect of Perception of Ease to Interest in the Use of E-filing}

According to Tjini and Baridwan (2010) argued that perception of ease is a belief in a person where in the use of a technology can be easily used and understood. Perceptions of ease will have an effect on behavior, ie the higher the perception someone about the ease of using the system, the higher the level of utilization of information technology.

According to Tjini and Baridwan (2010) argued that the perception of ease is a belief in a person where in the use of a technology can be easily used and understood. Perceptions of ease will have an impact on behavior, ie the higher the perception someone about the ease of using the system, the higher the level of utilization of information technology.

Based on literature review, grand theory and previous research, hypothesis can be formulated as follows:

$\mathrm{H} 2$ : Perceptions of ease has a positive effect on the use of E-Filing.

The Effect of Security and Confidentiality to Use of E-filing 
Regulation of the Director General of Taxation Number PER-32 / PJ / 2017 concerning amendment to the Regulation of the Directorate General of Taxation Number PER-41 / PJ / 2015 concerning the security of electronic transactions of the electronic tax service electronic system provided by the Directorate General of Taxation or other parties appointed by the Director General Taxes used by taxpayers to conduct electronic transactions with the Directorate General of Taxes which includes the Directorate General of Taxes online and the providers of SPT Electronic Services.

An information system can be said to be good if the security of the system is reliable. System security can be viewed through the data of the safe usage stored by an information system.

Task Technology Fit (TTF) Theory developed by Goodhue and Thompson (1995). TTF is the level at which technology assists the individual in the performance of his duties or job duties. This model indicates that performance will increase when a technology provides the right features and support associated with the task.

Research conducted by Poon (2008), Salim (2013), Wowor (2014) and Wahyuni (2015) stated that security and confidentiality have a positive effect on interest in using e-filing. However, the research results contradict the results of research conducted by Sugihanti (2011) which states that security and confidentiality does not affect corporate taxpayers in using e-filing. This is because the authorities provide security guarantees and data confidentiality, so taxpayers do not pay much attention to how powerful the technology device for security and confidentiality of information systems from e-filing.

Based on literature review, grand theory and previous research, hypothesis can be formulated as follows:

H3: Security and confidentiality have a positive effect on the use of E-Filing.

\section{Research Methods \\ Population and Sample}

This research is a quantitative research emphasizing on the theory test through measurement of research variables with numbers and data analysis with statistical procedure (Indriantoro and Supomo, 2014: 12). The population in this study is the number of taxpayers of the Agency registered in KPP Pratama Raba Bima consisting of Dompu Regency, Bima and Kota Bima, which is engaged in limited liability company, commodity company, firm, amounting to 350 taxpayers. The sampling technique is done by proportional stratified random sampling technique, which is proportional sampling technique to get representative sample. In this research use 75 Taxpayer as sample.

\section{Method of collecting data}

Data were collected by questionnaire survey based on previous research development which was closely related to the variables in this study. Questionnaire of a series of systematic and standardized questions so that the same questions can be asked to each respondent. Questionnaire is an effective data collection tool because it can be obtained standard data that can be accounted for the characteristics of the population studied (Suprianto, 2000). In this study the questionnaire is submitted directly to the Taxpayer Agency engaged in a limited liability company, commodity companies and firma.

\section{Data analysis method}

This study tested three exogenous variables and one endogenous variable. Exogenous variables consist of perception of utility, perception of ease, security and confidentiality. Endogenous variables consist of the use of e-filing. The research model can be designated in the following figure: 


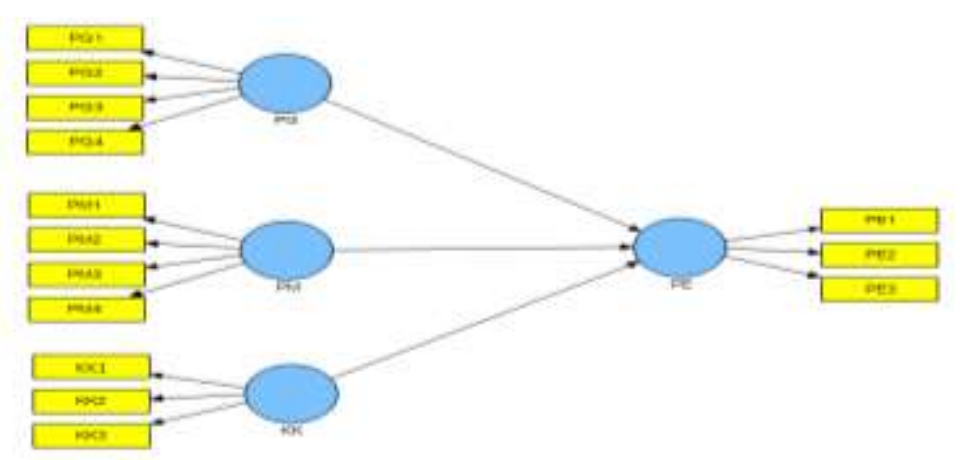

Figure 2. Structural Model

\section{Result And Discussion}

\section{Validity Test Results and Discriminant}

Validity testing involves the convergen and discriminant validity. Convergent validity is the extent to which the size is positively correlated with the alternative steps of the same construct. To measure the convergent validity by looking at the loading factor for each constructor indicator. Hair et al (2013) states that the load factor value must be greater than 0.7 because the latent variable can at least explain the variance of each indicator.

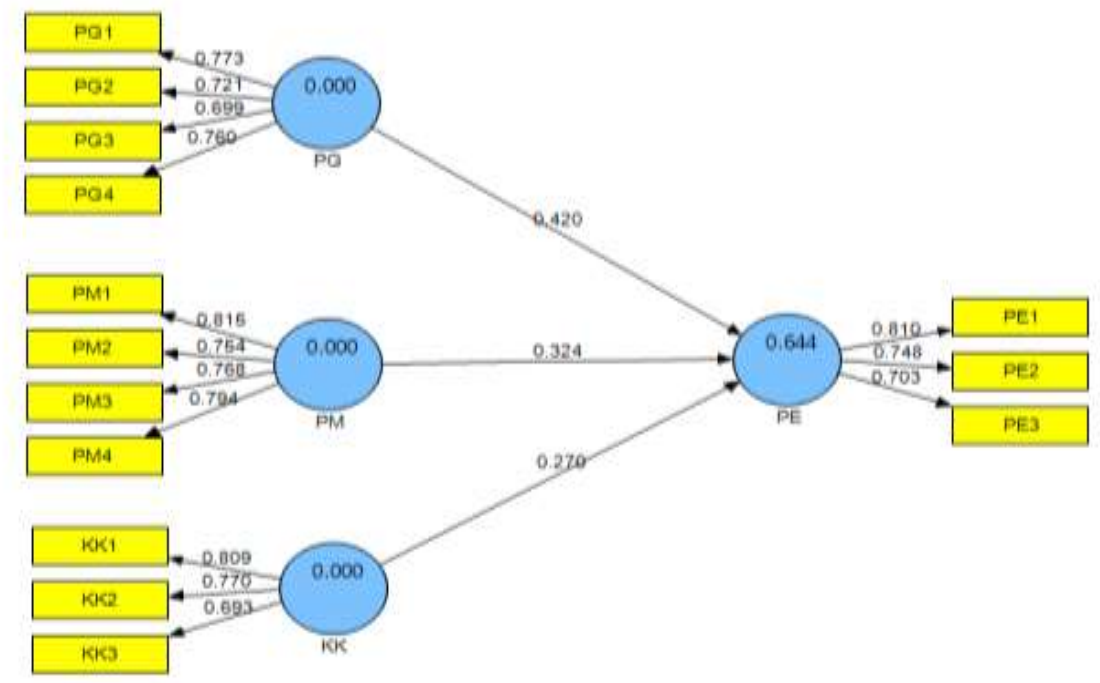

Figure 3. Outer model test results through Algorithm procedure

Figure 3 shows an indicator by loading a factor greater than 0.6 which is considered to have strong enough validity to explain its latent variables (meet convergen validity). Details of these indicators can be seen in table 1 below:

Table 1. Convergent Validity

\begin{tabular}{|c|c|c|c|c|}
\hline Variable & Indicator & Loading Factor & AVE & Communality \\
\hline \multirow{4}{*}{ PG } & PG1 & 0,773 & & \\
\cline { 2 - 3 } & PG2 & 0,721 & \multirow{2}{*}{0,546} & 0,546 \\
\cline { 2 - 3 } & PG3 & 0,699 & & \\
\cline { 2 - 3 } & PG4 & 0,760 & & \multirow{2}{*}{0,613} \\
\hline \multirow{3}{*}{ PM } & PM1 & 0,815 & 0,613 \\
\cline { 2 - 3 } & PM2 & 0,754 & & \\
\cline { 2 - 3 } & PM3 & 0,768 & & \\
\hline
\end{tabular}




\begin{tabular}{|c|c|c|c|c|}
\hline & PM4 & 0,794 & & \\
\hline \multirow{3}{*}{ KK } & KK1 & 0,809 & \multirow{3}{*}{0,576} & \multirow{3}{*}{0,576} \\
\hline & KK2 & 0,770 & & \\
\hline & KK3 & 0,693 & & \\
\hline \multirow{3}{*}{ PE } & PE1 & 0,810 & \multirow{3}{*}{0,570} & \multirow{3}{*}{0,570} \\
\hline & PE2 & 0,748 & & \\
\hline & PE3 & 0,703 & & \\
\hline
\end{tabular}

Source: PLS 2.0 output (2018)

In the above table the value of loading factor on all indicators for all latent variables has a loading factor greater than 0.6, this indicates that all indicators meet the requirements of convergent validity, in addition the AVE parameter values of all latent variables are also greater than 0.5.

Discriminant Validity

\begin{tabular}{|c|c|c|}
\hline Latent Variables & AVE & AVE Root \\
\hline PG & 0,546 & 0.739 \\
\hline PM & 0,613 & 0.783 \\
\hline KK & 0,576 & 0.759 \\
\hline PE & 0,570 & 0.755 \\
\hline
\end{tabular}

Source: PLS 2.0 output (2018)

Table 3. Intermediate Latent Correlation Values

\begin{tabular}{|c|c|c|c|c|}
\hline & PG & PM & KK & PE \\
\hline PG & 1.000000 & & & \\
\hline PM & 0.591213 & 1.000000 & & \\
\hline KK & 0.284964 & 0.370485 & 1.000000 & \\
\hline PE & 0.688115 & 0.67206 & 0.509461 & 1.000000 \\
\hline
\end{tabular}

Each variable shows an AVE root value greater than the correlation value between latent variables. Each latent variable qualifies for discriminant validity.

\section{Composite Reliability Test}

Reliability test is used to measure the reliability of a construct with reflective indicators (Ghozali and Latan, 2015: 75). A construct is said to be reliable if the value of composite reliability should be greater than 0.7 (Hair et al., 2014: 107). Composite reliability test results are presented in Table 4.

Table 4. Composite Reliability Value

\begin{tabular}{|c|c|c|c|}
\hline $\begin{array}{c}\text { Latent } \\
\text { Variables }\end{array}$ & $\begin{array}{c}\text { Composite } \\
\text { Reliability }\end{array}$ & $\begin{array}{c}\text { Cronbachs } \\
\text { Alpha }\end{array}$ & Information \\
\hline PG & 0.827636 & 0.722477 & Reliable \\
\hline PM & 0.863818 & 0.789742 & Reliable \\
\hline KK & 0.802133 & 0.630134 & Reliable \\
\hline PE & 0.798266 & 0.621679 & Reliable \\
\hline
\end{tabular}

Source: PLS 2.0 output (2018)

Based on table 4 above all latent variables have composite reliability values greater than 0.7 and the value of crombachs alpha is greater than 0.6. Thus it can be concluded that the variables in this study declared reliable because it meets the criteria in the composite reliability test. 
Structural model testing with PLS is seen from the R-Square (R2) value for each endogenous variable as predictor strength of the structural model. The classification of R-Square values according to Chin, (1998) in Ghozali and Latan (2015: 81) consists of 0.67 (strong), 0.33 (moderate), 0.19 (weak) .

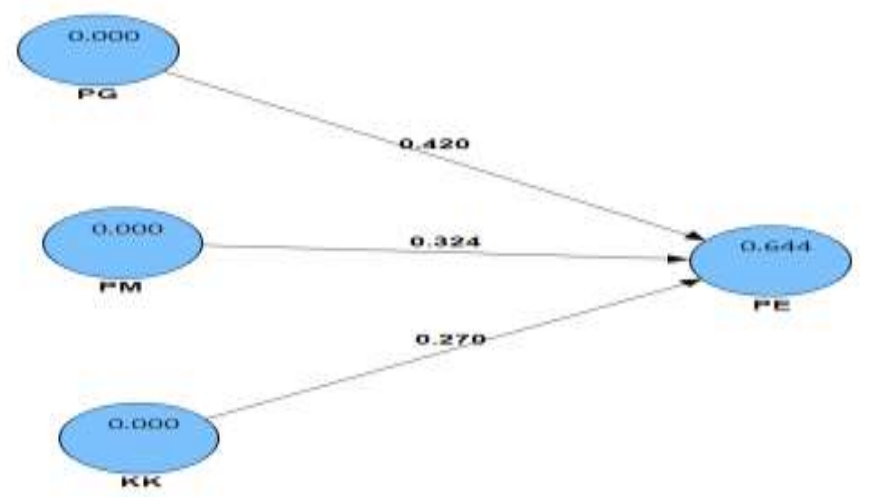

Figure 4. Test Result of Inner Model Using Algorithm Method

Based on Figure 4 above, the value of R-square (R2) of the variable relationship PG, PM, KK is 0.644. This shows that 64.4 per cent of the variables of e-filing use can be explained by PG, PM, and KK variables, while the remainder of 35.6 per cent is explained by other variables outside of this research model. The value of R-square (R2) of 0.644 shows a strong model according to Chin (1998) in Ghozali and Latan (2015: 81)

\section{Hypothesis Testing}

Hypothesis testing compares the t-statistics with t-tables generated from the bootstrapping process in the PLS. The results of hypothesis testing can be seen in Figure 5 results of bootstrapping process and Table 5 below

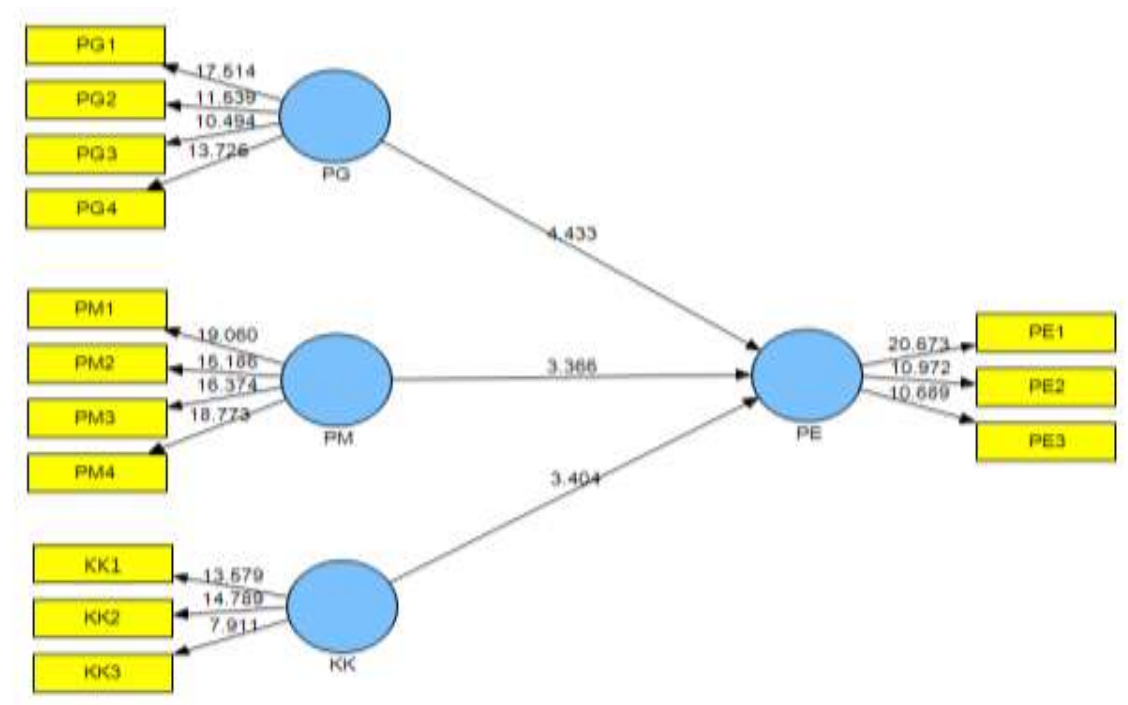

Figure 5. Boostrapping Process Results

Based on Table 5 the hypothesis can be seen from the comparison of t-statistics with t-tables. If the t-statistic value is higher than t-table then the hypothesis is supported / accepted. Level of significance used is 5 percent.

Table 5. Conclusion of Research Hypothesis

\begin{tabular}{|c|c|c|c|c|c|c|}
\hline Hypothesis & $\begin{array}{c}\text { Independent } \\
\text { Variables }\end{array}$ & $\begin{array}{c}\text { Path } \\
\text { Coefficient }\end{array}$ & $\mathbf{t}_{\text {stat }}$ & $\mathbf{t}_{\text {-tabel }}$ & Decision & Information \\
\hline
\end{tabular}




\begin{tabular}{|l|l|l|l|l|l|l|} 
& Perceptions of & & & & \\
H1 & Use & 0,420 & 4,433 & 1,96 & H1 accepted & Significant (+) \\
\hline H2 & $\begin{array}{l}\text { Perceptions of } \\
\text { ease }\end{array}$ & 0,324 & 3,366 & 1,96 & H2 accepted & Significant (+) \\
\hline H3 & $\begin{array}{l}\text { Security and } \\
\text { confidentiality }\end{array}$ & 0,270 & 3,404 & 1,96 & H3 accepted & Significant (+) \\
\hline
\end{tabular}

Source: PLS 2.0 Output (2018)

Hypothesis testing until decision making is described as follows:

1. Hypothesis Testing 1

The results of testing the first hypothesis states that the perception of use has a positive effect on the use of e-filing. The t-statistic value for the relationship between PG variables to PE is 4.433. The value is higher than the t-table value (1.96) at a significant level of 5 percent. Analysis of the direction of the relationship can be seen on the coefficient of the path value of 0.420 with a positive direction. Thus it can be concluded that use perception has a positive and significant effect on the use of e-filing. A decision can be made that the first hypothesis is accepted.

2. Hypothesis Testing 2

The results of the second hypothesis testing stated that perception of ease has a positive effect on the use of e-filing. The t-statistic value for the relationship between PM variables to PE is 3.366. The value is higher than the t-table value (1.96) at the 5 percent significant level, and the path coefficient value of 0.324 with the positive direction. Thus it can be concluded that the perception of ease has a positive and significant effect on the use of e-filing taxpayer Agency. A decision can be made that the second hypothesis is accepted.

3. Hypothesis Testing 3

The results of the third hypothesis testing that the Security and Confidentiality positive effect on the use of e-filing. The t-statistic value for the relationship between variables KK to PE is 3.404. The value is higher than the value of t-table (1.96) at a significant level of 5 percent, and the value of the path coefficient of 0.270 with a positive direction. Thus it can be concluded that Security and Confidentiality have a positive and significant effect on the use of e-filing taxpayer Agency. A decision can be made that the third hypothesis is accepted.

\section{Discussion}

\section{The Effect perception of use to Use of E-filing corporate Taxpayers}

Table 5 shows that the path coefficient between perception of use e-filing usage of 0.420 and tstatistics of 4.433 is greater than 1.96 (t-tables) at a significant level of 5 percent, so the first hypothesis is accepted. These results prove that the perception of use has a positive and significant effect on the use of efiling. These results support research findings conducted by Susantto (2011), Puspa (2012), Lie and Sadjiarto (2013), Laihad (2013), Noviandini (2013), Risal (2013), Wibisono (2014). This indicates if the user menginterprestasikan e-filing provides benefits in the submission of tax reports then taxpayers directly encouraged to use e-filing or in other words if the high perception of use then taxpayers interest in using efiling is also large.

\section{The Effect perception of ease to Use of E-filing corporate Taxpayers}

Table 5 shows that the path coefficient between ease of e-filing perception is 0.324 and t-statistic 3,366 is greater than 1,96 (t-tables) at 5 percent significant level. Thus the second hypothesis is accepted. These results prove that the perception of ease has a positive and significant impact on interest in the use of efiling. These results support previous research from Wiyono (2008), Susanto (2011), Noviandini (2012) and Laihad (2013). Based on the results of this study the perception of ease of affecting the level of use of efiling, the higher the level of convenience perception, the more often use e-filing. 


\section{The Effect Security and Confidentiality to Use of E-filing corporate Taxpayers}

Table 5 shows that the path coefficient between security and confidentiality to interest in e-filing usage of 0.270 and t-statistics of 3.404 is greater than 1.96 (t-tables) at a significant 5 percent level, so the third hypothesis is accepted. These results prove that security and confidentiality have a positive and significant effect on interest in using e-filing. This means that the use of e-filing system can provide security and maintain the confidentiality of taxpayer data so as to encourage corporate taxpayers to use e-filing in tax reporting.

\section{Conclusion:}

Based on the results of data analysis in this test shows that the perception of usablity has a positive and significant effect on the use of e-filing. This shows that if user interprets e-filing can give benefit in submitting tax report then direct taxpayer is encouraged to use e-filing.

The perception of ease has a positive and significant effect on the use of e-filing. This means that the perception of ease of self-confidence and sense of security in the activity so that someone would increase the use of e-filing, the easier the perception of corporate taxpayers in the use of e-filing facilities, the greater the level of confidence to use it. Security and confidentiality have a positive effect on the use of e-filing. This means that the use of e-filing system can provide security and maintain the confidentiality of taxpayer data so as to encourage corporate taxpayers to use e-filing.

\section{Limited Research}

This study certainly has many limitations, among others: first, data collection techniques used questionnaire, so the information obtained depends on the perception of respondents. Secondly, the scope of the research is limited to research in Dompu, Bima and Kota Bima districts of KPP Pratama Raba Bima, thus less able to generalize the use of e-filing especially in Indonesia. Third, this research is done by quantitative approach only, so it has lack in catch phenomenon related to the use of e-filing.

\section{Future Research Suggestions}

Further research is suggested in order to consider the following: first, to obtain more in-depth information on the research object would be better if adding data collection methods by interviewing respondents. Second, to expand the scope of research by adding objects such as districts/cities in Sumbawa and Lombok island or districts/cities in the province of West Nusa Tenggara. Third, change the research construct by using the moderation variable to see the difference of influence of each variable.

\section{References}

[1] Aulia Dyanrosi. 2015. Analisis Perilaku Wajib Pajak Terhadap Minat Perilaku Menggunakan E-Filing. JISIP: Jurnal Ilmu Sosial dan Ilmu Politik. ISSN. 2442-6962 Vol.4 No.2. Universitas Brawijaya.

[2] Chen, Shin-Chih, Shing-Han Li, and Chien-Yi Li. 2011. Recent Related Reseach in Technology Acceptance Model: A Literature Review. Australian Journal of Business and Management Reseach, Vol.1 No.9: 124-127.

[3] Davis, F.D. 1989. Perceived Usefulness, Perceived Ease of Use, and Acceptance of Information System Technologi. MIS Quarterly. Vol.13, N0.3:319-339. Delotte \& Touche LPP.2008. E-filing in the Netherlands. Part of The Move Tax Forward Series, 1-2

[4] Desmayanti, Esy. 2012. Faktor-faktor yang mempengaruhi penggunaan fasilitas e-filing oleh wajib pajak sebagai sarana penyampaian SPT Masa Secara Online dan Realtime ( Kajian Empiris di Kota Semarang). Universitas Diponegoro. Jurnal Riset Akuntansi Indonesia. Vol.1 No. 1-12.

[5] Direktorat Jenderal Pajak. 2004. Keputusan Direktur Jenderal Pajak Nomor KEP-88/PJ/2004 tentang $\begin{array}{llll}\text { Penyampaian } & \text { Surat } & \text { Pemberitahuan }\end{array}$ http://www.ortax.org/ortax/?=aturan\&page=show\&id=1354. 2018 
Tata Cara Penyampaian Surat Pemberitahuan secara Elektronik (e-filing) melalui Perusahaan Penyedia Jasa Aplikasi:

[7] $\quad$ http://kanwiljogja.pajak.go.id/ppajak.php?id=9334, 2018.

2008. Peraturan Direktorat Jenderal Pajak Nomor PER-47/PJ/2008 tentang Tata Cara Penyampaian Surat Pemberitahuan dan Penyampaian Pemberitahuan Perpanjangan Surat

Pemberitahuan secara Elektronik (e-filing) melalui Perusahaan Penyedia Jasa Aplikasi (ASP):

[9] http://www.ortax.org/ortax/?=aturan\&page=show\&id=1354. 2018.

Transaksi Elektronik Layanan Pajak Online.

[11] www.pajak.go.id/peraturan-direktur-jenderal-pajak-nomor-32pj2017. 2018.

[12] Ghazali, Imam dan Hengky, Latan. 2015. Partial Least Squarest Konsep, Teknik dan Aplikasi Menggunakan Program SmartPLS.3.0 Untuk Penelitian Empiris. Badan Penerbit Universitas Diponegoro Semarang. ISBN: 979.704.300.2

[13] Goodhue, D.L., and Thompson R.I. 1995. Task Technologi Fit and Individual Performance MIS Quartelrly, Vol.9 No.2: 213-236

[14] Hair, F Joseph, G.T.M. Hult, C.M. Ringle., and Marko Sarstedt. 2014. A Primer On Partial Least Square Structural Eqquation Modeling (PLS-SEM). California : Sage Publication.

[15] Hamlet C, Strube H. 2000. Community bank go online. ABA Banking Journal 2000 White Paper Banking on the interest, 1: 61-65.

[16] Indrianto, Nur dan Supomo, Bambang. 2014. Metodologi Penelitian Bisnis untuk Akuntansi dan Manajemen. Yogyakarta: BPFE

[17] Jogiyanto. (2010). Sistem Teknologi Informasi Edisi II. Yogyakarta: Andi

[18] Laihad, Risal C.Y. 2013. Pengaruh Perilaku Wajib Pajak Terhadap Penggunaan E-filing Wajib Pajak di Kota Manado. Jurnal Akuntansi, Vol.1 No.3: 44-51. ISSN: 2303-1174

[19] Lie, Ivana dan Arja Sadjiarto. 2013. Faktor-Faktor Yang Mempengaruhi Minat Perilaku Wajib Pajak Untuk Menggunakan E-Filing. Universitas Kristen Petra. Tax \& Accounting Review, Vol.3 No.2

[20] Noviandini, Nurul Citra. 2012. Pengaruh Persepsi Kebermanfaatan, Persepsi Kemudahan Penggunaan dan Kepuasan Wajib Pajak Terhadap Penggunaan E-Filing Bagi Wajib Pajak di Yogyakarta. Jurnal Nominal Vol.1 Nomor 1: 15-22.

[21] Poon, Wai Ching. 2008. User'adaption of e-banking services: the Malaysian perspective. Journal of Business \& Industrial Marketing, Vol.23 No.1: 59-69.

[22] Robbins, Stephen.P. 2008. Perilaku Organisasi. Edisi Bahasa Indonesia. Klaten: PT. Intan Sejati.

[23] Salim, Emil. 2013. Faktor-Faktor yang Mempengaruhi Penggunaan Fasilitas E-Filing oleh Wajib Pajak sebagai Sarana Penyampaian SPT Masa secara Online dan Realtime (Studi Empiris pada Wajib Pajak Badan di KPP Madya Jakarta Pusat). Jurnal Akuntansi. Fakultas Ekonomi. Sumatra Barat: Universitas Bung Hatta.

[24] Sugihanti, Winna Titis. 2011. Analisis Faktor-Faktor Yang Mempengaruhi Minat Perilaku Wajib Pajak Untuk Menggunakan E-Filing. Jurnal Universitas Diponegoro, Semarang. 
[25] Susanto, Nugraha Agung. 2011. Analisis Perilaku Wajib Pajak terhadap Penerapan Sistem E-Filing Direktorat Jenderal Pajak. Tesis. Fakultas Ekonomi. Jakarta: Universitas Indonesia.

[26] Tjini, Sartika Sari Ayu dan Zaki Baridwan. 2010. Pengaruh Kepercayaan, Persepsi Kegunaan, Persepsi Kemudahan, dan Persepsi Kenyamanan Terhadap Minat Penggunaan Sistem Internet Banking. Jurnal Universitas Brawijaya. Malang.

[27] Wahyuni, Resky. 2015. Pengaruh PersepsiKegunaan, Kemudahan, Keamanan dan Kerahasiaan, dan Kecepatan Terhadap Intensitas Perilaku Dalam Penggunaan E-Filing (Studi Pada Wajib Pajak Orangi Kantor Pelayanan Pajak Pratama Pekanbaru), Vol.2 No.2: 1-15.

[28] Wang, Yi-Shun, Tang L.H, Tzung-I. 2003. Determinan of user acceptance of Internet Banking: an empirical study. International Journal of service Industry Management.Vol.14 No.5: 501-519.

[29] Wibisono dan Agus. 2014. Analisis Faktor-faktor yang mempengaruhi Minat Wajib Pajak dalam penggunaan e-filing di Surabaya. Tax \& Accounting Review,Vol.4 No. 1: 1-15.

[30] Wiyono, Adrianto Sugiarto. 2008. Evaluasi Perilaku Penerimaan Wajib Pajak Terhadap Penggunaan E-filing sebagai Sarana Pelaporan Pajak Secara Online dan Realtime. Jurnal Riset Akuntansi Indonesia, Vol.11 No.2: 117-132

[31] Wowor, Rixky Alfiando, Jenny Morasa, dan Inggriani Elim. 2014. Analisis Faktor-Faktor Yang Mempengaruhi Perilaku Wajib Pajak Untuk Menggunakan E-Filing. Universitas Sam Ratulangi Manado. Vol.2 No.1: 1340-1349. 